\title{
Development and Evaluation of Context-Based Laboratory Activities in Chemistry Using Low-cost Kits for Junior Public High School
}

\author{
Richard R. Sagcal ${ }^{1 *}$, Nestor S. Valera ${ }^{2}$, Joel T. Maquiling ${ }^{3}$ \\ ${ }^{1}$ Science Department, Senior High School, Quezon City Science High School, Quezon City \\ ${ }^{2}$ Department of Chemistry, School of Science and Engineering, Loyola Schools, Ateneo de Manila University, \\ Katipunan Ave., Loyola Heights, Quezon City \\ ${ }^{3}$ Department of Physics, School of Science and Engineering, Loyola Schools, Ateneo de Manila University, \\ Katipunan Ave., Loyola Heights, Quezon City
}

\begin{abstract}
The main purpose of this study is to develop and validate context-based laboratory activities and low-cost kits for chemistry to improve the practical and laboratory skills of Grade-10 students in a junior public high school. These activities and kits during the fourth quarter (December 2016 - March 2017). The effectiveness of these teaching materials were assessed and quantified by 24 science teachers, one junior high school principal, and 30 student respondents using descriptive and quasi-experimental methods. A group of 30 students who were taught using traditional lecture-based methods served as the control. Standardized multiple-choice pre- and post-tests consisting of 65 items each were used to measure the mean gain performances of both groups of students. The pre-test was conducted to identify the topics least mastered by the students. For these groups, the topics deemed least mastered were stoichiometry and the ideal gas law. A post-test was also administered to both groups to gauge their understanding of these topics via mean gain scores. Data collected indicate that both the teacher and student respondents graded the context-based activities and low-cost kits as effective and highly acceptable (4.79 on a scale of 5 weighted mean). Mean gain scores increased significantly in the experimental group compared to the control group, with Hake's mean gain scores of 0.63 and 0.25 respectively. The mean scores and levels of mastery of students in the experimental group who used these materials were also significantly higher than those in the control group.
\end{abstract}

Keywords: context-based; low-cost kits; laboratory activities; improvisation; chemistry

\section{INTRODUCTION}

Science and technology play significant roles in the improvement of our quality of life, have a huge impact in our society. For students to appreciate advances in science and technology worldwide, it is necessary for educators to design, develop, and establish materials and practices help learners become more creative, critical and analytical thinkers (Kumar and Altschuld, 2004).
Among the scientific disciplines, chemistry is often perceived by learners as a difficult subject. Chemistry requires learners to actively infuse themselves in laboratory activities in order to improve their practical and laboratory skills and to achieve optimum scientific learning. However, chemistry education faces challenges arising from deficient laboratory materials and facilities, and ineffective 
teaching (Cainto, 2009). In many junior public high schools, it has been a practice among laboratory classes to limit the number of experiments to a minimum number in order to cope with the available resources (Lina, 2006). According to Solon (2006), the Philippine public school system continues to be plagued by inadequate budgets, and most schools are not capable of providing adequate laboratory training for students In addition, traditional lecture-based instructional methods are usually not effective, and education researchers have presented arguments that chemistry education should involve more hands-on and context-based learning.

Many educators have attempted to address these deficiencies by using low-cost and readily available materials, and by designing so-called contextbased laboratory activities. Context-based learning involves the use practical procedures and processes that focus on real-life applications of science topics discussed during classes. Context-based learning also promotes learning that highlights the interaction between the interests of learners and the standard classroom settings (Rose, 2012).

An increasing number of context-based laboratory activities make use of readily available and inexpensive materials (Haury and Rillero, 1994). For example, in the studies of Borford and Summerlin (1990), Cainto (2009), Cation (2012), and Horton (2011), low-cost laboratory equipment in chemistry were built as alternatives to standard laboratory equipment. These low-cost alternatives were validated and tested by expert teachers and users for effectiveness in. classroom settings

This work is an attempt to incorporate low-cost laboratory kits in a daily classroom setting. In particular, this work aims to evaluate the effectiveness of context-based laboratory activities and low-cost kits for chemistry teaching in the Grade-10 level in a junior public high school.

This work also aims to:

- describe the strengths and challenges in maintaining a chemistry laboratory in a junior public school;

- propose interventions to resolve the concerns in the chemistry laboratory; and

- measure the acceptability and effectiveness the context-based laboratory activities via teacher and student respondents.

\section{SURVEY INSTRUMENTS AND RESPONDENTS}

The main method for gathering information in this study was the descriptive survey for the existing chemistry laboratory in a junior public high school, and this was also used a basis in developing contextbased laboratory activities and low-cost science kits. A review of previous achievement tests (school year 2012-2015) were conducted to identify the least mastered topics in chemistry. A standardized pre-test and post-test were also used on grade- 10 students to identify topics which were least mastered. The topics deemed least mastered were stoichiometry and the ideal gas law.

This study also employed a non-probability purposive sampling method involving one junior high school principal, one curriculum developer from Department of Education National Capital Region (Deped NCR), 25 science teachers, and 60 student participants, a total of 87 respondents. The students were subdivided into two groups of 30 students each. The first group of students used the low-cost chemistry kits under supervision, while the second group which served as the control were taught using the traditional predominantly lectureonly method.

A similar study conducted by Mongcal (2017) also identified stoichiometry and ideal gas law as the least mastered topics.

Frequencies, means, and standard deviations were obtained from the various surveys conducted on the respondents. Likert scales were used in characterizing the responses.

The five-point Likert scale was used in assessing the chemistry laboratory room and its facilities are shown in Table 1.

Table 1. Pre-assessment of Chemistry Laboratory Room and Equipment.

\begin{tabular}{lll}
\hline $\begin{array}{l}\text { Range of } \\
\text { Mean }\end{array}$ & Level of Reactions & Qualities \\
\hline $4.51-5.00$ & Very evident (VE) & Very Good (VG) \\
\hline $3.51-4.50$ & Evident (E) & Good (G) \\
\hline $2.51-3.50$ & $\begin{array}{l}\text { Evident with } \\
\text { Reservation (ER) }\end{array}$ & Fair (F) \\
\hline $1.51-2.50$ & $\begin{array}{l}\text { Cannot Form an } \\
\text { Opinion (CFO) }\end{array}$ & Poor (P) \\
\hline $1.00-1.50$ & Not Evident (NE) & $\begin{array}{l}\text { Needs Improvement } \\
\text { (NI) }\end{array}$ \\
\hline
\end{tabular}

A similar five-point Likert scale was used in measuring the effectiveness of the improvised laboratory equipment as shown in Table 2 .

The Likert scale used by the respondents in validating the module containing context-based activities by respondent teachers and students is shown in Table 3. 
Table 2. Efficacy of the Alternative Laboratory Evaluation Tool.

\begin{tabular}{lll}
\hline $\begin{array}{l}\text { Range of } \\
\text { Mean }\end{array}$ & Level of Reactions & Qualities \\
\hline $4.51-5.00$ & Strongly Agree (SA) & Very Good (VG) \\
\hline $3.51-4.50$ & Agree (A) & Good (G) \\
\hline $2.51-3.50$ & $\begin{array}{l}\text { Agree with Reservation } \\
\text { (AR) }\end{array}$ & Fair (F) \\
\hline $1.51-2.50$ & Disagree (D) & Poor (P) \\
\hline $1.00-1.50$ & Strongly Disagree (SD) & Discarded (D) \\
\hline
\end{tabular}

Table 3. Instrument Validation by Teacher and Student Respondents.

\begin{tabular}{lll}
\hline $\begin{array}{l}\text { Range of } \\
\text { Mean }\end{array}$ & Verbal Interpretations & Qualities \\
\hline $4.51-5.00$ & $\begin{array}{l}\text { Highly Acceptable } \\
(\mathrm{HA})\end{array}$ & Very Good (VG) \\
\hline $3.51-4.50$ & Acceptable (A) & Good (G) \\
\hline $2.51-3.50$ & $\begin{array}{l}\text { Acceptable with } \\
\text { Reservation (AR) }\end{array}$ & Fair (F) \\
\hline $1.51-2.50$ & $\begin{array}{l}\text { Cannot Form an } \\
\text { Opinion (CFO) }\end{array}$ & Poor (P) \\
\hline $1.00-1.50$ & Unacceptable (U) & Discarded (D) \\
\hline
\end{tabular}

\section{RESULTS AND DISCUSSION}

The effectiveness of the developed and validated context-based laboratory activities and low-cost chemistry kits in junior public high school were evaluated. The statistical tool used is the twosampled t-test where in the p-value determines whether or not to reject the null hypothesis.

Strengths and Weaknesses of the Existing Laboratory. Pre-assessment survey form was given to teacher respondents to identify the strengths and weaknesses of the existing laboratory in terms of qualities for further improvement.

A summary of the laboratory status assessed by science teachers is shown in Table 4 below. It shows that the overall perceptions of the science teachers in the science laboratory was fair or evident with reservation (2.91 on a scale of 5 weighted mean). In general, the teacher respondents also rated the following laboratory features as fair or evident with reservation: the room and condition (3.06 weighted mean); student population (3.19 weighted mean); manpower resources (3.04 weighted mean); consumables (2.66 weighted mean); laboratory manuals (2.77 weighted mean); and facilities and equipment/materials ( 2.76 weighted mean).

The laboratory room and conditions, student populations, manpower resources, consumables, laboratory manuals and facilities were initially assessed. All aspects have shown fair qualities. The results show similar result to the study of Lina (2006), and Gonzales (1994).

Table 4. Summary of the Science Laboratory Status $(\mathrm{N}=25)$.

\begin{tabular}{llll}
\hline $\begin{array}{l}\text { Summary of the Science } \\
\text { Laboratory Status } \\
\text { Pre-assessment }\end{array}$ & WM & $\begin{array}{l}\text { Level of } \\
\text { Reactions }\end{array}$ & Qualities \\
\hline $\begin{array}{l}\text { A. Rooms and } \\
\text { Conditions }\end{array}$ & 3.06 & ER & F \\
\hline B. Student Population & 3.19 & ER & F \\
\hline C. Manpower Resources & 3.04 & ER & F \\
\hline D. Consumables & 2.66 & ER & F \\
\hline E. Laboratory Manuals & 2.77 & ER & F \\
\hline $\begin{array}{l}\text { F. Facilities and } \\
\text { Equipment/ Materials }\end{array}$ & 2.76 & ER & F \\
\hline Overall Average $=$ & 2.91 & ER & F \\
\hline Legend: WM-weighted mean; $N$-total population & \\
\hline
\end{tabular}

The rank of the science laboratory concerns based on the weighted means assessed by the 25 science teachers is shown in Table 5 below.

Though the laboratory status were assessed evident with reservation in general based on the average weighted mean of each features, the data show that the laboratory status was rated fair or moderately evident in utilizing or using improvised laboratory equipment/materials in replacement of the standard ones. Consequently, the improvised equipment/ materials were assessed as fair or moderately evident in serving their purpose. The use of lowcost chemicals and reagents in replacement of the standard laboratory consumables, and the periodic purchase of consumables were evaluated as fair or moderately evident. In addition, the improvised equipment/materials were assessed as fair or moderately evident in terms of safety in handling and in assembling.

Therefore, the improvisation and utilization of low-cost laboratory materials were highly needed and recommended in replacement of the standard laboratory equipment/materials. Furthermore, the reconstruction or improvement of laboratory rooms and conditions terms having exhaust blower, sufficient exit doors and readily available electricity, water, gas facilities and operating well was also needed in improving the quality of the laboratory.

Identifying the Learners' Least Mastered Topics and Skills in Chemistry. The study used the previous data and results of the school's achievement (periodical examination) tests and 
Table 5. Rank of the Science Laboratory Top Concerns ( $\mathrm{N}=25)$.

\begin{tabular}{|c|c|c|c|c|}
\hline Rank & Category & $\begin{array}{l}\text { Science } \\
\text { Laboratory Top } \\
\text { Concern }\end{array}$ & WM & Qualities \\
\hline 1.5 & \multirow[t]{2}{*}{ D. Consumables } & $\begin{array}{l}\text { 5. Uses low-cost } \\
\text { chemicals and } \\
\text { reagents in } \\
\text { replacement of } \\
\text { the standard } \\
\text { laboratory } \\
\text { consumables. }\end{array}$ & 2.16 & $\mathrm{~F}$ \\
\hline 1.5 & & $\begin{array}{l}\text { 6. There is } \\
\text { a periodic } \\
\text { purchase of } \\
\text { consumables } \\
\text { done in all } \\
\text { laboratories }\end{array}$ & 2.16 & $\mathrm{~F}$ \\
\hline 3 & \multirow{2}{*}{$\begin{array}{l}\text { G. Facilities and } \\
\text { Equipment/ } \\
\text { Materials }\end{array}$} & $\begin{array}{l}\text { 9. Improvised } \\
\text { equipment/ } \\
\text { materials served } \\
\text { their purpose. }\end{array}$ & 2.20 & $\mathrm{~F}$ \\
\hline 4 & & $\begin{array}{l}\text { 10. Improvised } \\
\text { equipment/ } \\
\text { materials are safe } \\
\text { to handle and } \\
\text { easy to assemble. }\end{array}$ & 2.24 & $\mathrm{~F}$ \\
\hline 5 & $\begin{array}{l}\text { A. Rooms and } \\
\text { Conditions }\end{array}$ & $\begin{array}{l}\text { 10. Science } \\
\text { laboratory } \\
\text { rooms are } \\
\text { provided with } \\
\text { exhaust blowers } \\
\text { to drive fumes } \\
\text { away as well as } \\
\text { sufficient and } \\
\text { exit doors. }\end{array}$ & 2.36 & $\mathrm{~F}$ \\
\hline 6.5 & $\begin{array}{l}\text { G. Facilities and } \\
\text { Equipment/ } \\
\text { Materials }\end{array}$ & $\begin{array}{l}\text { 8. The } \\
\text { laboratory uses } \\
\text { improvised } \\
\text { equipment/ } \\
\text { materials in } \\
\text { replacement of } \\
\text { the standard } \\
\text { one. }\end{array}$ & 2.40 & $\mathrm{~F}$ \\
\hline 6.5 & $\begin{array}{l}\text { A. Rooms and } \\
\text { Conditions }\end{array}$ & $\begin{array}{l}\text { 11. Electricity, } \\
\text { water, gas, and } \\
\text { other facilities } \\
\text { are readily } \\
\text { available in } \\
\text { the Science } \\
\text { laboratory and } \\
\text { are operating } \\
\text { well. }\end{array}$ & 2.40 & Fair \\
\hline
\end{tabular}

Table 6. Least Mastered Topics in Grade-10 Chemistry.

\begin{tabular}{ll}
\hline $\begin{array}{l}\text { Grading } \\
\text { Period }\end{array}$ & Least Mastered Topics \\
\hline Fourth & $\begin{array}{l}\text { Chemical Reaction (top 1), Gas Laws: Boyle's Law } \\
\text { (top 10) and Charles Law (top 10) }\end{array}$ \\
\hline
\end{tabular}

their corresponding item-analysis and identified the top ten (10) least mastered topics in chemistry for grade 10 level. The items that scored low in the school division periodical tests from School Year (SY) 2014-2015 to SY 2016-2017 were the topics of ideal gases, and stoichiometry.

Standardized pretests by Pearson (2013) were also given at the onset of the second grading and fourth grading periods to verify the least mastered topics obtained from the previous periodical assessments in chemistry.

The least mastered topics of grade 10 learners in chemistry is shown Table 6 below. The data gathered were very similar to the data obtained by the unpublished study of Mongcal (2017). In the work of Mongcal (2017), the content topics of chemical reactions and gas laws ranked top $3(40.67 \%)$ and top $5(40.67 \%)$ in the recent conducted content knowledge test given to 38 selected chemistry teachers in different public schools. It can be inferred from the data that there is a high need of developing teaching materials in the topics listed below.

\section{Chemistry in a Box Kit and Context-based}

Activities. The context-based activities and low-cost chemistry kits were similar to the structure of the kits of Horton (2011), Borgford and Summerlin (1990), and Brand (2009). The chemistry kits have laboratory modules infused with context-based laboratory activities. As much as possible, learners were not required to bring science laboratory materials from their homes to school as part of their homework. Rather, all laboratory materials and equipment needed in the experiments were already provided by the teacher and placed inside the portable chemistry box kits. These materials are readily available to use by the learners anytime during the activity. Since the chemistry kits were all portable, the laboratory activities were not limited to be performed inside the laboratory $\operatorname{room}(s)$. Instead, the teacher and learners could actually bring the chemistry kits inside their classroom to resolve the problem in having lesser number of laboratory rooms, and in having learners' tendency to forget to bring the assigned materials in school. If all science classes were given the opportunity to provide all the materials needed in experiments, there will be minimal or no missed laboratory activities in school. Also, the laboratory activities were made simple and short so that learners had more time analyzing their group data and results as similar to the study of Parisi and Turner (2008).

The chemistrykits were conceptualized and developed to reinforce scientific concepts and appreciate its real-life applications. The procedures in the context- 
based laboratory activities were translated from English to Filipino (Tagalog) language for the better understanding of the public high school learners. The use of binocular communication in the study was necessary to the learners who were in the lower sections. This result to better communication, translations of knowledge, acquiring of skills and meaningful learning. There were 8 context-based activities performed by the learners.

\begin{abstract}
Development of Context-based Laboratory Activities and Low-cost Chemistry Kits. The 8 context-based activities included in study aimed to enhance the mean performances of the learners and to improve their manipulative and laboratory skills in chemistry. Preparing of solutions and materials needed, measuring mass and volume, proving gas laws, balancing chemical equations in a given chemical reaction, and titrating acetic acids to mention some of the 8 context-based activities used in the study. These context-based activities have provided students opportunities in developing their science process skills such as observing, interpreting, planning, designing experiments and testing out hypothesis and ideas. Most of all, the intervention material was developed to improve the mean gain performances of the learners, to inspire students study chemistry with less anxiety and to encourage chemistry teachers to develop more intervention material like this in other topics in chemistry.
\end{abstract}

The use of low-cost or locally and readily available materials were considered to make gas laws and chemical reaction activities relevant, meaningful and interesting to students. Similarly, this context-based activities has been developed based on the following considerations. First, activities must be parallel with the objectives of the K-12 science curriculum. Second, the activities made use of context-based activities to see the relevance of the topics in their daily lives. Prior to the implementation of the intervention, the study identified that students have difficulty in understanding English text instruction related to laboratory procedure based on the initial observation. Third, activities must encourage the use low-cost or locally and readily available materials and inexpensive chemical substances. Fourth, laboratory activities must be short and simple, and the improvise instrument used in the experiment must be easily constructed and accessible. Finally, the activities must be conducted in either science laboratory room or classroom using appropriate and safe procedure. The materials included in contextbased activities and low-cost chemistry kits are shown Figure 1 below.

Figure 1 shows the materials and substances used in performing the 8 context-based activities in

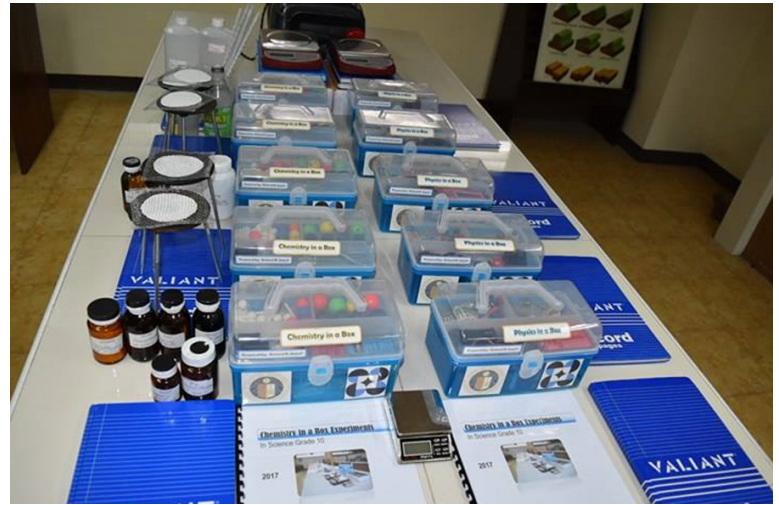

Figure 1. Low-cost Chemistry Kits.

chemistry. All low-cost materials were placed inside the kits and each kit has corresponding modules.

In this study, the low-cost materials and substances used in the activities on gas laws include: $20 \mathrm{~g}$ table salt, $10 \mathrm{~mL}$ syringe, small stick/stirrer (coffee stirrer), improvised thin-stem barrel pipette, icecandy container, denatured alcohol, liquid dropper, ruler, $10 \mathrm{~g}, 20 \mathrm{~g}$, and $30 \mathrm{~g}$ of commercial baking soda, $250 \mathrm{~mL}$ commercial vinegar, 3 small balloons, and electronic balance scale. While the following lowcost materials were used in the chemical reactions activities: commercial muriatic acid, one old and new penny (1 peso or 5 peso coin), chewing gum pocket blister, drinking straws, iron powder, powdered chalk, sodium hydroxide $(0.1 \mathrm{M})$, burette (courtesy of UP NISMED), and improvised bottle or container. Figure 2 shows the low-cost materials used in proving gas law: Boyle's law activity. This activity used improvised thin stem barrel pipette in investigating the relationship between volume and pressure at constant temperature. The efficacy of the improvised material was also validated by expert or teacher respondents.

The contents of the low-cost chemistry kits and the context-based laboratory activities are shown in Table 7. It can be deemed from the table that the objectives set were parallel to the new K-12 science curriculum and the materials were readily available from the market. All materials needed in

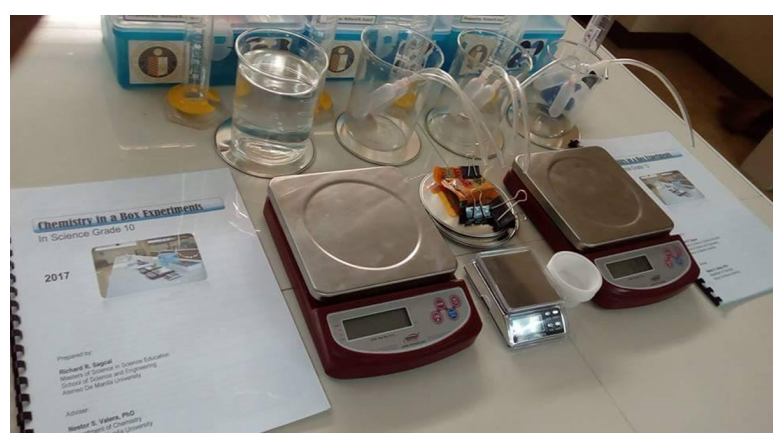

Figure 2. Low-cost Materials in Proving Gas Law: Boyle’s Law Activity. 
Table 7. Contents of the Low-cost Chemistry Kit and Context-based Laboratory Activities.

\begin{tabular}{|c|c|c|c|}
\hline Experiment & Purposes & Equipment Supplied in a Box Kit & $\begin{array}{l}\text { Materials Supplied by } \\
\text { the Learners }\end{array}$ \\
\hline $\begin{array}{l}\text { Activity } 1 \\
\text { Gas Laws: Investigating } \\
\text { Charles' Law }\end{array}$ & $\begin{array}{l}\text { investigate the relationship } \\
\text { between volume and } \\
\text { temperature at constant } \\
\text { gas pressure }\end{array}$ & $\begin{array}{l}\text { - } 10 \text {-mL or } 20-\mathrm{mL} \text { or } 30-\mathrm{mL} \text { syringe } \\
\text { - lubricant grease (vacuum/silicon grease) } \\
\text { - } \text { small stick } \\
\text { - } \text { ice (for ice water bath) } \\
\text { - } 20.0 \mathrm{~g} \text { salt } \\
\text { - } \text { water } \\
\text { - } \text { electric heater } \\
\text { - } 4 \text { pcs } 500 \text {-mL beakers } \\
\text { - } 4 \text { thermometers } \\
\text { - } 4 \text { stirring rods }\end{array}$ & $\begin{array}{l}\text { - } 5 \text { pcs. Graphing paper } \\
\text { - Laboratory notebooks } \\
\text { (record book) } \\
\text { - calculator }\end{array}$ \\
\hline $\begin{array}{l}\text { Activity } 2 \\
\text { Gas Laws: Investigating } \\
\text { Boyle's Law }\end{array}$ & $\begin{array}{l}\text { investigate the relationship } \\
\text { between volume and } \\
\text { pressure at constant } \\
\text { temperature }\end{array}$ & $\begin{array}{l}\text { - improvised thin stem barrel pipette } \\
\text { - food coloring } \\
\text { - } 2 \text { pcs, } 250 \text {-mL beakers } \\
\text { - ice-candy container } \\
\text { - glue-stick }\end{array}$ & $\begin{array}{l}\text { - } 5 \text { pcs bond paper } \\
\text { - laboratory notebooks } \\
\text { (record book) } \\
\text { - calculator } \\
\text { - ruler }\end{array}$ \\
\hline $\begin{array}{l}\text { Activity } 3 \\
\text { Combined Gases' Laws }\end{array}$ & $\begin{array}{l}\text { determine the relationship } \\
\text { among temperature, } \\
\text { pressure, and volume at } \\
\text { constant number of moles }\end{array}$ & $\begin{array}{l}\text { - liquid dropper } \\
\text { - cylindrical container with cover } \\
\text { - denatured alcohol } \\
\text { - match/candle } \\
\text { - ruler } \\
\text { - } \text { sturdy paper }\end{array}$ & $\begin{array}{l}\text { - laboratory notebooks } \\
\text { (record book) } \\
\text { - calculator }\end{array}$ \\
\hline $\begin{array}{l}\text { Activity } 4 \\
\text { Avogadro's Law }\end{array}$ & $\begin{array}{l}\text { investigate the } \\
\text { relationship between } \\
\text { volume and number of } \\
\text { moles(n) at constant gas } \\
\text { pressure and temperature } \\
\text { experimentally }\end{array}$ & $\begin{array}{l}\text { - } 8 \text {-oz empty soda (plastic) bottle } \\
\text { - } 10 \mathrm{~g} ; 20 \mathrm{~g} \text {; and } 30 \mathrm{~g} \text { sodium bicarbonate (baking } \\
\text { soda) } \\
\text { - } 30 \mathrm{~mL} ; 40 \mathrm{~mL} ; 50 \mathrm{~mL} \text { acetic acid (vinegar) } \\
\text { - } 3 \text { balloons of the same size } \\
\text { - electronic balance } \\
\text { - } 1 \mathrm{pc}(500-\mathrm{mL}) \text { beaker } \\
\text { - graduated cylinder }\end{array}$ & $\begin{array}{l}\text { - laboratory notebooks } \\
\text { (record book) } \\
\text { - calculator }\end{array}$ \\
\hline $\begin{array}{l}\text { Activity } 5 \\
\text { Chemical Reactions: How } \\
\text { to Make Coins Float? }\end{array}$ & $\begin{array}{l}\text { investigate different } \\
\text { properties of two metallic } \\
\text { elements, zinc and copper; } \\
\text { and make observations } \\
\text { and inference }\end{array}$ & $\begin{array}{l}\text { - hydrochloric acid }(\mathrm{HCl}), 6 \mathrm{M} \text { (about } 20 \mathrm{~mL}) \\
\text { - } \text { one new penny (1983 or latest year) } \\
\text { - } 100-\mathrm{mL} \text { beaker }\end{array}$ & $\begin{array}{l}\text { - laboratory notebooks } \\
\text { (record book) } \\
\text { - calculator } \\
\text { - ruler }\end{array}$ \\
\hline $\begin{array}{l}\text { Activity } 6 \\
\text { Effect of Acids on Metals }\end{array}$ & $\begin{array}{l}\text { observe how acids react } \\
\text { with metals; describe } \\
\text { the production of } \\
\text { bubbles (effervescence) } \\
\text { particularly; and describe } \\
\text { how magnesium reacts } \\
\text { strongly (by producing } \\
\text { more heat and more } \\
\text { bubbles) with acid than } \\
\text { iron does, using a less } \\
\text { amount acid }\end{array}$ & $\begin{array}{l}\text { - } \text { chewing gum pocket blister } \\
\text { - diagonally-cut drinking straws } \\
\text { - } \text { scissors } \\
\text { - disposable gloves } \\
\text { - } \text { safety glasses } \\
\text { - } 1 \text { drinking-straw tip of iron powder }\end{array}$ & $\begin{array}{l}\text { - laboratory notebooks } \\
\text { (record book) } \\
\text { - calculator }\end{array}$ \\
\hline $\begin{array}{l}\text { Activity } 7 \\
\text { Effects of Acid on } \\
\text { Carbonates }\end{array}$ & $\begin{array}{l}\text { observe how acids react } \\
\text { with carbonates; observe } \\
\text { the production of } \\
\text { bubbles (effervescence) } \\
\text { particularly; infer that the } \\
\text { gas present in the bubbles } \\
\text { is carbon dioxide }\end{array}$ & $\begin{array}{l}\text { - chewing gum blister packet } \\
\text { - diagonally-cut drinking straws } \\
\text { - scissors } \\
\text { - disposable gloves } \\
\text { - safety glasses } \\
\text { - } \text { powdered chalk }\left(\mathrm{CaCO}_{3}\right) \\
\text { - } \text { sodium bicarbonate }\left(\mathrm{NaHCO}_{3}\right) \\
\text { - hydrochloric acid solution }(15 \% \mathrm{w} / \mathrm{w} \text { or } 1 \mathrm{M})\end{array}$ & $\begin{array}{l}\text { - laboratory notebooks } \\
\text { (record book) } \\
\text { - calculator }\end{array}$ \\
\hline $\begin{array}{l}\text { Activity } 8 \\
\text { Titrating Acetic Acid }\end{array}$ & $\begin{array}{l}\text { determine the acetic acid } \\
\text { content of the commercial } \\
\text { vinegar }\end{array}$ & $\begin{array}{l}\text { - } \text { commercial vinegar } \\
\text { - } \text { phenolphthalein indicator } \\
\text { - } 0.1 \mathrm{M} \text { Sodium Hydroxide }(\mathrm{NaOH}) \\
\text { - low-cost buret (courtesy of UP) } \\
\text { - Erlenmeyer flask / improvised bottle container }\end{array}$ & $\begin{array}{l}\text { - laboratory notebooks } \\
\text { (record book) } \\
\text { - calculator }\end{array}$ \\
\hline
\end{tabular}


the context-based activities were already provided in the box except for those that most of the learners usually have in school such as laboratory notebooks, papers and calculator. Also, there were common set of materials to be used by the learners such as low-cost electronic balance, $\mathrm{pH}$ meter, molecular models, alternative chemicals and reagents. These common materials lessen the total costing in each chemistry box. The contents of low-cost Chemistry kits and context-based laboratory activities based on the identified least mastered topics. These activities are somewhat similar to the study of Digo (2001).
The breakdown of expenses of materials in constructing the low-cost chemistry kits is shown in Table 8 . The total cost per box is 142.55 pesos. A lot of money and resources were saved by the school using these chemistry kits. The same results and impression was made in the study of Freundenberg (2012); and (Parisi and Turner 2008). The specific venues where the materials of the kits can be bought are also shown in the table below. The venues were easily accessed by everyone in case of replenishing of materials.

\section{Table 8. Contents of the Low-cost Chemistry Kit and Context-based Laboratory Activities.}

\begin{tabular}{|c|c|c|c|c|}
\hline \multicolumn{5}{|c|}{ Materials for the Construction and Development of Chemistry in a Box Experiments } \\
\hline Location (Venue) & Item & Quantity & Price per piece & Proposed Budget \\
\hline \multicolumn{5}{|c|}{ Microscale Reagents / Chemicals } \\
\hline Bambang Stalls & Sodium Hydroxide $(\mathrm{NaOH})$ powder & $100 \mathrm{~g}$ & 160.00 & 160.00 \\
\hline Bambang Stalls & Phenolphthalein Indicator Solution & $100 \mathrm{~mL}$ & 200.00 & 200.00 \\
\hline \multicolumn{5}{|c|}{ Low-cost (Cheap) Reagents/Chemicals } \\
\hline Grocery Stores & Silver swan Commercial Vinegar (Acetic Acid) & $385 \mathrm{~mL}$ & 13.50 & 13.50 \\
\hline Grocery Stores & Ferna Baking Soda (Sodium Bicarbonate) & $500 \mathrm{~g}$ & 37.50 & 37.50 \\
\hline Grocery Stores & PVL Iodized Salt (Sodium Chloride) & $500 \mathrm{~g}$ & 14.50 & 14.50 \\
\hline Pharmacy (Watsons) & Rhea Agua Oxigenada (Hydrogen Peroxide) & $100 \mathrm{~mL}$ & 25.00 & 25.00 \\
\hline National Bookstore & White Hi-dustless chalk (Calcium bicarbonate) & 100 pcs & 0.42 & 42.00 \\
\hline Hardware & Denatured Alcohol & $250 \mathrm{~mL}$ & 35.00 & 35.00 \\
\hline Grocery Stores & Muriatic Acid & $250 \mathrm{~mL}$ & 95.00 & 95.00 \\
\hline \multicolumn{5}{|c|}{ Low-Cost (Cheap) Laboratory Instruments/Equipment } \\
\hline Bambang Stalls & Dropper (glass) $(10 / \mathrm{pc})$ & 5 pcs & 10 & 50.00 \\
\hline Bambang Stalls & Safety goggles $(40 / \mathrm{pc})$ & 5 & 40 & 200.00 \\
\hline Bambang Stalls & Test-tube holders $(20 / \mathrm{pc})$ & 5 pcs & 20 & 100.00 \\
\hline Bambang Stalls & Test tubes (small) $(5 / \mathrm{pc})$ & $25 \mathrm{pcs}$ & 5 & 125.00 \\
\hline SM Department Store & Chemistry Box (P 79.75 / pc) & 5 pcs & 79.75 & 398.75 \\
\hline Grocery Stores & Water resistant safety matches & 1 box & 17.75 & 17.75 \\
\hline Bambang Stalls & Electronic Balance Batteries (AAA) & 8 pcs & 24 & 24.00 \\
\hline Bambang Stalls & Container jars small (glasses) & 5 pcs & 0 & 0 \\
\hline \multirow[t]{2}{*}{ Bambang Stalls } & Container jars large (glasses) & 5 pcs & 0 & 0 \\
\hline & Glue Sticks & 6 pcs & 24.75 & 24.75 \\
\hline SM Ace Hardware & Plastic tubing & 2 meters & 4.125 & 20.00 \\
\hline Fastfoods & Straws (c/o fast-food) & 10 pcs & 0 & 0.00 \\
\hline Recycled Materials & Improvised Spot- plates (gum pocket blisters) & 10 pcs & 0 & 0.00 \\
\hline Recycled Materials & Improvised sample containers $(25 \mathrm{ml})$ & 40 pcs & 0 & 0.00 \\
\hline Recycled Materials & Improvised spatula (Halo-halo spoons) & 20 pcs & 0 & 0.00 \\
\hline Recycled Materials & Improvised plastic vials $(1 \mathrm{oz})$ & 50 pcs & 0 & 0.00 \\
\hline Recycled Materials & Recycled glass bottled vials $(10 \mathrm{~mL}, 25 \mathrm{~mL}, 50 \mathrm{~mL})$ & 30 pcs & 0 & 0.00 \\
\hline Recycled Materials & Improvised beakers -Nestle Yogurt plastic $(25 \mathrm{~mL})$ & 5 pcs & 0 & 0.00 \\
\hline National Bookstore & $\begin{array}{l}\text { Other materials needed for the improvisation of lab } \\
\text { equipment (e.g. strong glue, cups, wire, electrical } \\
\text { tape, etc.) }\end{array}$ & 1 set & & 200.00 \\
\hline SUBTOTAL & & & & 1782.75 \\
\hline COST PER BOX & & & & 142.55 \\
\hline
\end{tabular}


The common materials used in chemistry laboratory activities are shown in Table 9. These materials were easily accessed by the students during the conduct of the activities.

Comparison in the Expenses of the Low-cost and the Standard Laboratory Equipment/ Materials.

TThe expenses or costs in the low-cost and standard laboratory equipment/materials were compared in terms of cost practicality and replication purposes. Table 10 shows the comparison of the prices in the commonly used materials in the standard and low-cost materials. It can be deemed from the table that the low-cost chemistry kits were four times less expensive than the standard laboratory materials. In addition, one chemistry kit only cost 142.55 pesos. The chemistry kits contained all the necessary materials in all context-based activities at a very affordable price. In fact, almost 129 sets of chemistry kits can be replicated in chemistry using the budget in the standard laboratory materials which costs $18,414.00$ pesos. Moreover, the materials used in the chemistry kits were readily available in the market and can be afforded using minimal budget only, and no shipping or delivery fee is required.

The data obtained from expert respondents in validating the tool are shown in Table 11 below. It further shows that the verbal interpretation of the expert respondents in all components were highly acceptable or very good as shown in their equal weighted means (WM $=4.83$ ).

Generally, the expert respondents validated the instrument tool as highly acceptable or very good as shown on the average weighted mean of 4.83 . It can be inferred from the results that the expert respondents rated the evaluation very good or highly acceptable in terms of its assessment is congruent to the performed activities (WM=4.83), assessment determines learners' attainment of the objectives (WM=4.83), assessment provided reallife applications of the topic presented (WM=4.83), assessment provides adequate feedback on the teaching learning process of the learners (WM=4.83), assessment improves learners' higher order thinking skills (WM=4.83).

Learners' Learning Performance Assessment. This study aimed to measure the effectiveness of the context-based activities and low-cost science kits in increasing the learning mean performance of the learners. Table 12 and 13 show the results of the pretest and post-test of the students in the experimental and control group in chemistry subject. The mean average of the experimental group is higher than the mean average of the control group. It was evident from here that the learners scored high
Table 9. Common Materials Used in Chemistry.

\begin{tabular}{|c|c|c|c|}
\hline Item & Quantity & $\begin{array}{r}\text { Price per } \\
\text { piece }\end{array}$ & $\begin{array}{r}\text { Proposed } \\
\text { Budget }\end{array}$ \\
\hline $\mathrm{pH}$ meter & $1 \mathrm{pc}$ & 2200.00 & 2200.00 \\
\hline $\begin{array}{l}\text { Electronic } \\
\text { heater }\end{array}$ & $1 \mathrm{pc}$ & 1400.00 & 1400.00 \\
\hline $\begin{array}{l}\text { Electronic } \\
\text { balance }\end{array}$ & $1 \mathrm{pc}$ & 500.00 & 500.00 \\
\hline $\begin{array}{l}\text { Molecular } \\
\text { model }\end{array}$ & $1 \mathrm{pc}$ & 1200.00 & 1200.00 \\
\hline $\begin{array}{l}\text { Electronic } \\
\text { Balance } \\
\text { Batteries } \\
\text { (AAA) }\end{array}$ & 8 pcs & 24.00 & 24.00 \\
\hline SUBTOTAL (in Php) & & & 5324.00 \\
\hline
\end{tabular}

Table 10. Comparison between the Standard and Low-cost Expenses of the Common Materials Needed in Chemistry.

\begin{tabular}{lcrr}
\hline Item & Quantity & $\begin{array}{r}\text { Standard } \\
\text { Material Price }\end{array}$ & $\begin{array}{r}\text { Low Cost } \\
\text { Material Price }\end{array}$ \\
\hline $\mathrm{pH}$ meter & $1 \mathrm{pc}$ & $3,400.00$ & $2,200.00$ \\
\hline $\begin{array}{l}\text { Electronic } \\
\text { heater }\end{array}$ & $1 \mathrm{pc}$ & $3,200.00$ & $1,400.00$ \\
\hline $\begin{array}{l}\text { Electronic } \\
\text { balance }\end{array}$ & $1 \mathrm{pc}$ & $11,717.00$ & 500.00 \\
\hline $\begin{array}{l}\text { Electronic } \\
\text { Balance } \\
\text { Batteries } \\
\text { (AAA) }\end{array}$ & $8 \mathrm{pcs}$ & 97.00 & 24.00 \\
\hline TOTAL (in Php) & & & $\mathbf{1 8 , 4 1 4 . 0 0}$ \\
\hline
\end{tabular}

Table 11. Tool Validation in Chemistry Assessed by Experts: Evaluation (N-12).

\begin{tabular}{lccl}
\hline Evaluation & WM & SD & $\begin{array}{l}\text { Verbal } \\
\text { Interpretation }\end{array}$ \\
\hline $\begin{array}{l}\text { 1. The assessment is } \\
\text { congruent to the performed } \\
\text { activities. }\end{array}$ & 4.83 & 0.39 & $\begin{array}{l}\text { Highly } \\
\text { acceptable }\end{array}$ \\
\hline $\begin{array}{l}\text { 2. The assessment } \\
\text { determines learners } \\
\text { attainment of the } \\
\text { objectives. }\end{array}$ & 4.83 & 0.39 & $\begin{array}{l}\text { Highly } \\
\text { acceptable }\end{array}$ \\
\hline $\begin{array}{l}\text { 3. The assessment provides } \\
\text { real-life applications of the } \\
\text { topic presented. }\end{array}$ & 4.83 & 0.39 & $\begin{array}{l}\text { Highly } \\
\text { acceptable }\end{array}$ \\
\hline $\begin{array}{l}\text { 4. The assessment provides } \\
\text { adequate feedback on the } \\
\text { teaching learning process of } \\
\text { the learners. }\end{array}$ & 4.83 & 0.39 & $\begin{array}{l}\text { Highly } \\
\text { acceptable }\end{array}$ \\
\hline $\begin{array}{l}\text { 5. The assessment improves } \\
\text { learners' higher order } \\
\text { thinking skills. }\end{array}$ & 4.83 & 0.39 & $\begin{array}{l}\text { Highly } \\
\text { acceptable }\end{array}$ \\
\hline \begin{tabular}{l} 
Average \\
\hline
\end{tabular} & 4.83 & 0.39 & $\begin{array}{l}\text { Highly } \\
\text { acceptable }\end{array}$ \\
\hline
\end{tabular}

Legend: WM - Weighted Mean; SD - Standard Deviation 
Table 12. Results of Pretest and Posttest in Chemistry S.Y. 2016-2017.

\begin{tabular}{|c|c|c|}
\hline $\begin{array}{c}\text { Experimental } \\
\text { Group (A) }\end{array}$ & Pretest & Posttes \\
\hline 1 & 16 & 48 \\
\hline 2 & 19 & 51 \\
\hline 3 & 16 & 41 \\
\hline 4 & 18 & 53 \\
\hline 5 & 19 & 42 \\
\hline 6 & 19 & 37 \\
\hline 7 & 23 & 49 \\
\hline 8 & 16 & 53 \\
\hline 9 & 16 & 59 \\
\hline 10 & 14 & 44 \\
\hline 11 & 13 & 39 \\
\hline 12 & 14 & 55 \\
\hline 13 & 19 & 49 \\
\hline 14 & 21 & 40 \\
\hline 15 & 12 & 47 \\
\hline 16 & 20 & 60 \\
\hline 17 & 9 & 43 \\
\hline 18 & 20 & 42 \\
\hline 19 & 17 & 57 \\
\hline 20 & 8 & 38 \\
\hline 21 & 13 & 38 \\
\hline 22 & 13 & 56 \\
\hline 23 & 22 & 48 \\
\hline 24 & 22 & 58 \\
\hline 25 & 13 & 53 \\
\hline 26 & 19 & 41 \\
\hline 27 & 26 & 48 \\
\hline 28 & 16 & 35 \\
\hline 29 & 11 & 37 \\
\hline 30 & 18 & 50 \\
\hline MEAN = & 16.73 & 47.03 \\
\hline MASTERY $(\%)=$ & 25.74 & 72.35 \\
\hline$\langle\mathrm{g}\rangle=$ & 0.21 & \\
\hline
\end{tabular}

in the posttest or even higher after implementing the low-cost chemistry kits and context-based laboratory activities in chemistry.

It was therefore found out that the use of the context-based laboratory and low-cost chemistry kits significantly increased the mean scores of learners in the pretest and posttest. The mean score of the pretest in the experimental group (section A) is only 16.73 while it became 47.03 during the posttest. Consequently, the percentages of mastery level of the learners in particular topics also increased positively from $25.74 \%$ to $72.35 \%$. While the mean score of the pretest in the control group (section $\mathrm{B}$ )
Table 13. Results of Pretest and Posttest in Chemistry S.Y. 2016-2017.

\begin{tabular}{|c|c|c|}
\hline Control group (B) & Pretest & Posttest \\
\hline 1 & 20 & 33 \\
\hline 2 & 14 & 29 \\
\hline 3 & 13 & 27 \\
\hline 4 & 17 & 32 \\
\hline 5 & 11 & 24 \\
\hline 6 & 20 & 29 \\
\hline 7 & 27 & 36 \\
\hline 8 & 21 & 33 \\
\hline 9 & 20 & 32 \\
\hline 10 & 17 & 21 \\
\hline 11 & 13 & 25 \\
\hline 12 & 24 & 33 \\
\hline 13 & 23 & 29 \\
\hline 14 & 16 & 30 \\
\hline 15 & 16 & 37 \\
\hline 16 & 21 & 30 \\
\hline 17 & 18 & 27 \\
\hline 18 & 13 & 22 \\
\hline 19 & 16 & 27 \\
\hline 20 & 15 & 30 \\
\hline 21 & 17 & 29 \\
\hline 22 & 17 & 23 \\
\hline 23 & 12 & 19 \\
\hline 24 & 17 & 39 \\
\hline 25 & 16 & 22 \\
\hline 26 & 20 & 40 \\
\hline 27 & 20 & 29 \\
\hline 28 & 13 & 28 \\
\hline 29 & 23 & 29 \\
\hline 30 & 22 & 44 \\
\hline MEAN = & 17.73 & 29.60 \\
\hline$\%$ MASTERY= & 27.28 & 45.54 \\
\hline$\langle\mathrm{g}\rangle=$ & 0.54 & \\
\hline
\end{tabular}

is only 17.73 while it became 29.60 in the posttest. Consequently, the percentages of mastery level of the learners in particular topics also increased positively from $27.28 \%$ to $45.54 \%$. There was drastic change in the mean scores and percentage of mastery in the pre and posttest of the experimental group than the control group.

The mean gain score $<\mathrm{g}>$ of the control group is 0.21 and the mean gain score $<\mathrm{g}>$ of the experimental group is 0.54 , there is a significant difference between the mean gains of the two groups based on the parameter of the course of Hake. 
Figures 3 and 4 below show the graphical representation of the comparison of the pretestposttest mean scores and percentage of mastery in chemistry. It can be inferred from the figures that students in the experimental group has higher posttest mean and posttest percentage of mastery, thus greater mean gain than the control groups.

The gain scores in the pretest and posttest of the control and experimental groups in chemistry are shown in Table 14 below. It can be inferred from the table that students in the experimental group has twice greater gain scores than the control group. All students in the experimental group showed positive gain scores in chemistry pre-and-posttest.

Since there was a notable significant difference between the pretest and posttest mean gain scores of the two groups, it indicated that experimental group performed better in the posttest than the control group after using the context-based laboratory activities and low-cost chemistry kits. Based on Table 15 , the values $\mathrm{t}(52)=11.347 ; \mathrm{p}<0.001$ indicated that there was remarkable significant difference between the mean gain scores of the two groups. Thus, they were unequal footing in terms of mean gain in the conceptual understanding in chemistry. The experimental group has higher mean gain score than the control group having a mean difference of 0.377 .

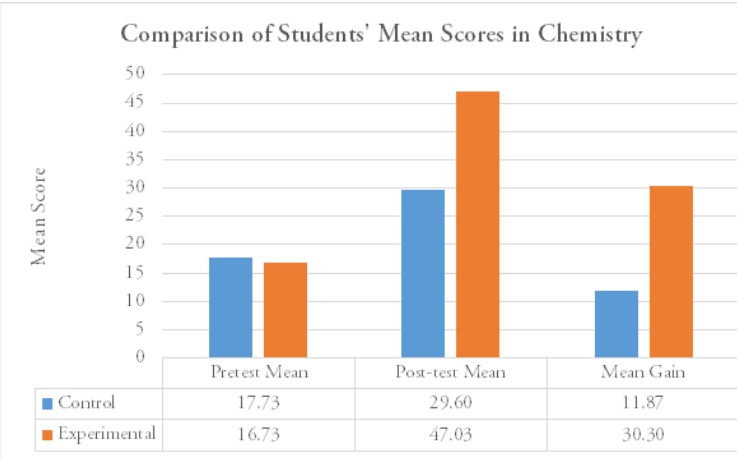

Figure 3. Comparison of Students' Mean Scores in Chemistry.

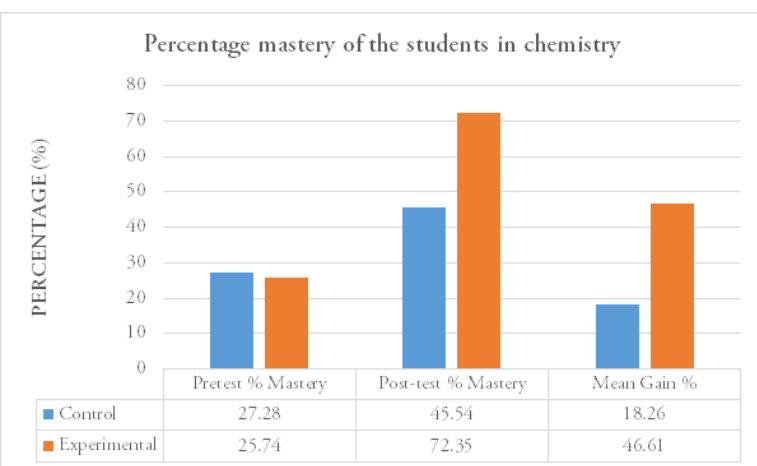

Figure 4. Students' Percentage Mastery in Chemistry .
Table 14. Gain Scores in the Pretest and Posttest of the Control and Experimental Groups in Chemistry.

\begin{tabular}{|c|c|c|}
\hline \multirow{2}{*}{$\begin{array}{c}\mathbf{n}=\mathbf{3 0} \\
\text { Student }\end{array}$} & \multicolumn{2}{|c|}{ Gain Scores in Chemistry } \\
\hline & Control & Experimental \\
\hline 1 & 0.289 & 0.653 \\
\hline 2 & 0.294 & 0.696 \\
\hline 3 & 0.269 & 0.510 \\
\hline 4 & 0.313 & 0.745 \\
\hline 5 & 0.241 & 0.500 \\
\hline 6 & 0.200 & 0.391 \\
\hline 7 & 0.237 & 0.619 \\
\hline 8 & 0.273 & 0.755 \\
\hline 9 & 0.267 & 0.878 \\
\hline 10 & 0.083 & 0.588 \\
\hline 11 & 0.231 & 0.500 \\
\hline 12 & 0.220 & 0.804 \\
\hline 13 & 0.143 & 0.652 \\
\hline 14 & 0.286 & 0.432 \\
\hline 15 & 0.429 & 0.660 \\
\hline 16 & 0.205 & 0.889 \\
\hline 17 & 0.191 & 0.607 \\
\hline 18 & 0.173 & 0.489 \\
\hline 19 & 0.224 & 0.833 \\
\hline 20 & 0.300 & 0.526 \\
\hline 21 & 0.250 & 0.481 \\
\hline 22 & 0.125 & 0.827 \\
\hline 23 & 0.132 & 0.605 \\
\hline 24 & 0.458 & 0.837 \\
\hline 25 & 0.122 & 0.769 \\
\hline 26 & 0.444 & 0.478 \\
\hline 27 & 0.200 & 0.564 \\
\hline 28 & 0.288 & 0.388 \\
\hline 29 & 0.143 & 0.481 \\
\hline 30 & 0.512 & 0.681 \\
\hline
\end{tabular}

Table 15. Independent Sample t-Test Result of the Pretest and Posttest Gain Score the Control and Experimental Groups in Chemistry $(n=30)$.

\begin{tabular}{ccccccc}
\hline Groups & Mean & SD & t-value & df & $\begin{array}{c}\text { p-value } \\
\text { Sig. } \\
\text { (2-tailed) }\end{array}$ & Decision \\
\hline $\begin{array}{c}\text { Control } \\
\text { Group }\end{array}$ & 0.251 & 0.104 & & & & \\
\cline { 1 - 2 } $\begin{array}{c}\text { Experi- } \\
\text { mental } \\
\text { Group }\end{array}$ & 0.628 & 0.149 & & 52 & $\mathrm{p}<0.001$ & $\begin{array}{c}\text { Reject } \\
\text { Null Hy- } \\
\text { pothesis }\end{array}$ \\
\hline
\end{tabular}


Learners' Evaluation on Context-based
Laboratory Activities and Low-cost Chemistry

Kits. The leaners evaluated the context-based laboratory activities and low-cost chemistry kits based on features indicated in the summary of the instrument validation as shown in Table 16 below. Overall, the learners strongly agreed that the instrument was valid and very good based on its indicators or features.

\section{CONCLUSION AND RECOMMENDATIONS}

In conclusion, the implementation of the contextbased laboratory activities and low-cost chemistry kit significantly increased the posttest's mean scores, and percentages of mastery level of the learners in the experimental group than the control group. Hence, the use of the low-cost chemistry kits was very effective in helping learners to perform better in posttests. The results are similar to the results of the study of Cainto (2009), Cation (2012), and Sevilla (2015). Therefore, intervention was very effective in increasing the level of performance of the learners. Several recommendations were suggested in this study. The researcher suggested to have better sampling techniques, have more respondents from private and public schools. Similar studies with some modifications in terms of depth and breadth should be done to verify the consistency of the low-cost science kits in teaching chemistry. More low-cost science kits can be replicated to teach more topics in chemistry, physics, biology and earth science. Other designs can also be applied for intervention. It is also recommended for teachers to apply the intervention not only in laboratory but also in lectures to identify other factors affecting students' mean gain score.

\section{ACKNOWLEDGEMENT}

The authors would like to express their deepest gratitude to the Department of Science and Technology - Science Education Institute (DOSTSEI) headed by Dr. Josette T. Biyo for the research grant and their usual support. Special thanks and endless appreciation to the Ateneo de Manila University - School of Science and Engineering headed by Dr. Evangeline P. Baustista for the further support. Richard R. Sagcal also acknowledges the DOST-SEI National Consortium in Graduate Science and Mathematics Education (NCGSME) for the scholarship grant, and is thankful to Dr. Nestor S. Valera and Dr. Joel T. Maquiling, the thesis advisers, and of course to Dr. Catherine Genevieve B. Lagunzad, the Master of Science in Science Education (MSSE) coordinator for their usual support and excellent supervision.
Table 16. Summary of Instrument Validation in Physics Assessed by Learners $(n=30)$.

\begin{tabular}{lll}
\hline $\begin{array}{l}\text { Summary of Instrument } \\
\text { Validation by Learners }\end{array}$ & WM & $\begin{array}{l}\text { Level of } \\
\text { Reactions }\end{array}$ \\
\hline A. Overview & 4.79 & SA \\
\hline B. Key Concepts & 4.54 & SA \\
\hline C. Objectives & 4.76 & SA \\
\hline D. Materials & 4.97 & SA \\
\hline E. Procedure / Activities & 4.87 & SA \\
\hline F. Guide Questions & 4.82 & SA \\
\hline G. Conclusion & 4.81 & SA \\
\hline Overall Average & 4.80 & SA \\
\hline Legend: WM - Weighted Mean $n-$ total sample size &
\end{tabular}

Legend: WM - Weighted Mean; $n$ - total sample size

\section{REFERENCES}

Borgford CL and Summerlin LR. Chemical Activities. Teacher edition. United States of American (USA): American Chemical Society; 1990. 330p.

Brand. The Exploratorium Science Snackbook. Exploratorium. Joessy-bass A Wiley Print. San Francisco California. 2009.

Cainto C. The Development of Low Cost Separatory Equipment: Water Condenser, Separatory Funnel and Centrifuge. Unpublished thesis [Master's Thesis]. Ateneo de Manila University; 2009.

Cation M. The Development and Design of Lowcost Chemistry Laboratory Instruments in Teaching High School Chemistry: Centrifuge and Portable Flame Test Kit. Unpublished thesis [Master's Thesis]. Ateneo de Manila University; 2012.

Digo GS. Development and Validation of Laboratory Activities in Bicol University. Unpublished thesis [Master's Thesis]. Bicol University- High School Department; 2001.

Freudenberg K. Science Snacks- A parent initiative brings learning home with ease. Vol. 37. Science and Children. National Science Teachers Association; 2012. p.37-41.

Gonzales LG. Chemistry Laboratory Facilities and Equipment in Secondary Schools of the Mindanao State University System: An Assessment and Proposed Development Plan. Unpublished thesis [Master's Thesis]. University of San Carlos Cebu City; 1994.

Haury D and Rillero P. Perspective of HandsOn Science Teaching: The ERIC Clearinghouse for Science. Mathematics and Environmental 
Education. Columbus. Ohio. 1994.

Horton M. Take-home Chemistry: 50 Low-Cost Activities to Extend Classroom Learning. National Science Teachers Association Press. 2011.

Kumar DD and Altschuld JW. Science Technology and Society. American Behavioral Scientist, 47, p. 1358-1367. 2004.

Lina R. A Proposed Development Plan in Chemistry and Physics Laboratories at Philippine State College of Aeronautics. Unpublished thesis [Master's Thesis]. Philippine State Colloge of Aeronautics; 2006.

Mongcal YC. Content Knowledge and Self-efficacy of Science Teachers: A Basis for the Development of Learning Modules in Chemistry. Unpublished thesis [Master's Thesis]. Ateneo De Manila University; 2017

Parisi and Turner. A take-home Physics experiment kit for on-campus and off-campus learners. 2008. Teaching Science. Australian Science Teachers Association. Vol 54 June 2008. p. 20-23 Retrieved January 15, 2017 from http://asta.edu.au

Pearson. Chemistry Practice Test Tennessee End of Course Assessment. State of Tennessee Department of Education. NCS Pearson Inc. Iowa City. State of Tennessee. 2013. Retrieved December 3, 2017, from: https:/www.tn.gov/assets/entities/education/ attachments/tst_eoc_chem_practice_test.pdf

Rose DE. Context-Based Leaning. 2012. Encyclopedia of the Sciences of Learning. Springer Science \& Business Media. 2012. Available from: http://www.springerlink.com/content/ x25677874688873p/fulltext.html [Accessed 27th August 2015]

Sevilla III F. Improving Chemical Education in the Philippines. International Union of Pure and Applied Chemistry. Vol.30 No.4. 2015. Available from: from: http://www.iupac.org/publications/ ci//2008/3004/cc2_170408.html [Accessed 20th August 2015]

Solon P. Public school system worst hit by lack of budget. Manila Bulletin. 402 (29).B7. 2006. 